\title{
Weak effects of farming practices corresponding to agricultural greening measures on farmland bird diversity in boreal landscapes
}

\author{
Johan Ekroos $\cdot$ Juha Tiainen $\cdot$ Tuomas Seimola $・$ Irina Herzon
}

Received: 11 April 2018/ Accepted: 28 January 2019/Published online: 8 February 2019

(C) The Author(s) 2019

\begin{abstract}
Context The current Common Agricultural Policy (CAP) of the European Union includes three greening measures, which are partly intended to benefit farmland biodiversity. However, the relative biodiversity effects of the greening measures, including joint effects of landscape context, are not well understood. Objectives We studied the effects of increasing crop diversity, proportions of production grasslands and fallows, corresponding to CAP greening measures, on open farmland bird diversity, whilst controlling for the
\end{abstract}

Electronic supplementary material The online version of this article (https://doi.org/10.1007/s10980-019-00779-x) contains supplementary material, which is available to authorized users.

J. Ekroos $(\square)$

Centre for Environmental and Climate Research, Lund University, 22362 Lund, Sweden

e-mail: johan.ekroos@cec.lu.se;

jeekroos@gmail.com

J. Tiainen · T. Seimola

Natural Resources Institute Finland, P. O. Box 2,

00790 Helsinki, Finland

\section{Herzon}

Department of Agricultural Sciences, 00140 Helsinki, Finland

\section{Herzon}

Helsinki Institute of Sustainability Science, HELSUS,

P. O. 20 Box 65, 00140 Helsinki, Finland effects of distance to forests, field edge density and proportion of built-up areas.

Methods We surveyed open farmland birds using territory mapping in Southern Finland. We modelled effects of greening measures and landscape structure on farmland birds (7642 territories) using generalised linear mixed models.

Results Increasing proportions of grasslands increased farmland bird species richness and diversity in open farmland, whereas increasing proportions of fallows increased bird diversity. Increasing crop diversity benefited individual species, but not species richness or diversity. Increasing field edge densities consistently increased the species richness of all farmland species, in-field nesters and non-crop nesters, as well as total farmland bird diversity. The relative effect of edge density was much stronger compared to the three greening measures.

Conclusions Our results show that promoting fallows and grasslands, in particular grazed grasslands and various types of semi-natural grasslands, has the highest potential to benefit farmland bird diversity. Maintaining or increasing field edge densities, currently not supported, seems to be of even more benefit. In open farmland, with little or no field edges, fallows and grasslands are particularly beneficial.

Keywords Agri-environment schemes · Common whitethroat · Greening under Pillar I - Meadow pipit · Skylark · Whinchat 


\section{Introduction}

The European Union (EU) has set a target of stopping biodiversity declines within the Union's member states by 2020 (European Commission 2011). In European farmland, the main policy approach to counteract widespread biodiversity declines are agrienvironment schemes funded under Common Agricultural Policy (CAP) (Pe'er et al. 2014). While some targeted agri-environment schemes have been highly successful in reversing declines of red-listed species (Perkins et al. 2011), many widely adopted agrienvironment schemes have been criticised for not being particularly effective (Kleijn et al. 2011). The recent CAP reform introduced so-called greening measures to address challenges related to climate change and the environment, including the decline of biodiversity (Pe'er et al. 2014).

The greening measures include establishing ecological focus areas over a certain portion of a farm area, retention of permanent grasslands and enhancing crop diversity (European Commission 2013). It has been argued that the greening measures in their approved form became less biodiversity-friendly than originally intended (Pe'er et al. 2014) and they are not based on solid evidence (Dicks et al. 2014). For example, ecological focus areas were originally suggested to consist of fallows or buffer strips, but later additional options, such as legumes under conventional management, were approved as ecological focus areas though their value for biodiversity can be questioned (Pe'er et al. 2014). Retention rules for permanent grasslands became less strict than originally proposed: a reduction of up to $5 \%$ in their net area at national or regional scales is permitted (Pe'er et al. 2014). Finally, the outcome of numerous exemptions resulted in that these measures apply to only $50 \%$ of EU farmland (ibid).

Because the biodiversity effects of the current greening measures are largely unknown but the imperative of improving environmental performance of the CAP remains strong, there is a clear need for further empirical evidence (Dicks et al. 2014; Pe'er et al. 2017). In addition, the added value of management interventions for farmland biodiversity depends on landscape context (Batáry et al. 2011; Scheper et al. 2013). Implementing greening measures may therefore have a stronger impact on farmland biodiversity in structurally simple landscapes, where wildlife- friendly management can create a stronger ecological contrast between areas with and without agri-environment schemes (Batáry et al. 2011). Moreover, birds breeding in open farmland avoid settlements and other built-up areas and forest edges, whereas predominantly open field boundaries are particularly beneficial non-crop habitat structures (Vepsäläinen et al. 2010; Tiainen and Seimola 2014). In this context, implementing greening measures can be expected to affect farmland birds differently depending on the availability of field boundaries and distance to forests and settlements across agricultural landscapes. Furthermore, individual species can be expected to respond differently to gradients in land-use intensity and landscape structure depending on contrasting ecological requirements between species (Vepsäläinen et al. 2010; Pickett and Siriwardena 2011).

Bird species breeding in fields respond directly to changes in field management practices, particularly in open farmland characterised by large fields and low proportions of non-crop habitats. In contrast, bird species breeding in edge habitats, e.g. in non-crop field boundaries, but feeding at least partially in fields, respond to field management indirectly because of effects of landscape complementation and landscape supplementation (Brotons et al. 2005; Smith et al. 2014; Josefsson et al. 2017). While farmland birds benefit from fallows (van Buskirk and Willi 2004; Herzon et al. 2011) and grasslands in cereal-dominated farmland (Piha et al. 2007), it is less clear whether increasing crop diversity benefits farmland birds (Hiron et al. 2015; Josefsson et al. 2017). Importantly, the relative effects of fallows, grasslands and crop diversity on bird assemblages are virtually unknown, in particular considering moderating effects of structural landscape attributes.

In anticipation of research specifically focused at the greening measures implementation and its benefits, this study focuses at the relative benefits of the field types that existed before the policy reform but that correspond to the greening measures in their functional role for farmland birds. To this end, in our study (i) ecological focus areas are represented by fallows of various kinds (legume crops are not included due to their low occurrence), (ii) permanent grasslands are indicated by all grasslands except rotational silage leys (see methods), and (iii) crop diversity is calculated based on seven main crop types. We focus on open farmed landscapes in a boreal zone 
to study the relative effects of three measures corresponding to the greening measures on farmland bird diversity and on the abundance of the most common species, while also testing for interactive effects between the greening measures and landscape variables. We use an extensive data-set collected in Southern Finland (Fig. 1), and we explicitly considered all bird species breeding in open farmland habitats. We expected grasslands and fallows to benefit farmland bird diversity to a larger extent than crop diversity (Josefsson et al. 2017), and because we focus on bird species breeding in open farmland we also expected stronger effects further away from forest edges (Piha et al. 2007; Wretenberg et al. 2010) and in landscapes characterised by low shares of built-up areas (Vepsäläinen et al. 2010). Finally, because of larger ecological contrasts (Kleijn et al. 2011), we expected stronger effects of greening measures in farmland with low availability of non-crop field boundaries.

\section{Materials and methods}

\section{Study area}

We used bird data collected during 2009-2011 in 47 survey areas situated within an area of $400 \times 150 \mathrm{~km}$ across Southern Finland (Fig. 1; Supporting material S1). Finland is divided into three zones with different levels of agricultural subsidies, and our study areas were situated in zones A and B, containing $21 \%$ and $26 \%$ of Finland's utilised agricultural area, respectively. In Finland, the greening measures are only

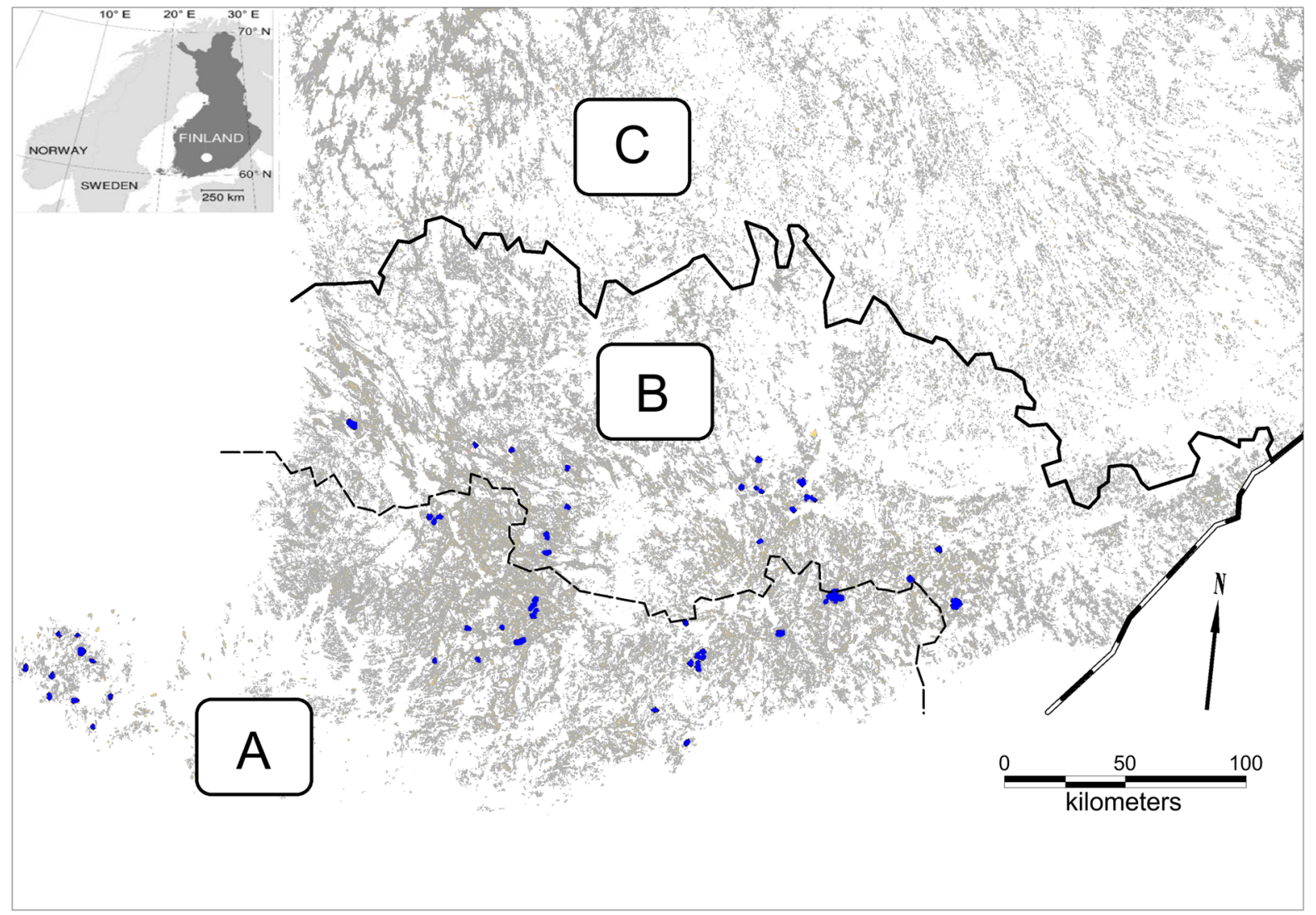

Fig. 1 Study area and the greening policy zonation in southern Finland. The continuous line delineates the southern agricultural support areas ( $\mathbf{a}$ and $\mathbf{b}$ ) where three crop plants are demanded in farms larger than 30 ha, and northern area $\mathrm{C}$ where only two crop plants is required. South of the dashed line (a), farms larger than 15 ha are expected to found ecological focus areas constituting $5 \%$ of their field area. Dots show the location of study areas in their true size. Land area is indicated by light grey shading and agricultural fields with dark grey shading 
applied to the three southern-most provinces while the rest are exempted due to a high forest cover. The nationally approved measures include diversification of cultivation with at least three crop plants in farms over 30 ha or two crop plants in farms with 10-30 ha in southern Finland (zones A and B, see Fig. 1) or two crop plants in farms over 10 ha further north (zone C), and an ecological focus area of 5\% of field area in farms over 15 ha in zone A (Finlex 2017). The area of semi-natural grasslands or over five years old cultivated grasslands are to be retained within $95 \%$ of a national reference value based on the surface area in 2015 (132,000 ha). The requirement of 5\% ecological focus areas can be achieved through permanent grassland, different kinds of fallows, short-term coppice and legume crops in farms larger than 15 ha.

Finnish farmland consists of mosaic landscapes where agricultural land is concentrated to patches of farmland surrounded by forest or other land use types. The size of these farmland patches vary from a few to several hundreds of hectares. Because of this mosaic structure, farmland patches contain well-delineated local communities of farmland birds. In this study, the 47 survey areas were delineated based on the extent of individual farmland patches, i.e. farmed areas surrounded by forested areas. Because the farmland patches varied in size, the survey areas also varied in size (mean $\pm \mathrm{SD}=234.2 \pm 263.04$, ha, $\min =80$, $\max =1675$; Supporting material S1). Survey areas either constituted an entire farmland patch or subsets of larger farmland patches, in which several survey areas were delineated to cover the farmland patches. As far as possible we used data collected in 2010, but when the 2010 data were not available we used data from 2009 or 2011. The total area surveyed was 12,300 ha, of which 10,572 ha represented cultivated land.

Field surveys and data preparation

We surveyed farmland birds using a territory mapping method with three survey rounds during early May to mid-June. The territory mapping was undertaken by a team of experienced field ornithologists, where each team member surveyed slightly over 100 ha farmland during one morning. Beginning at sunrise and ending roughly before noon, all farmland habitats within the survey area were thoroughly searched for farmland birds, which were marked on visit maps paying particular care to simultaneous observations on birds of neighbouring territories. Based on the three visit maps we interpreted the position of individual bird territories, which were subsequently represented as point objects in a GIS layer.

We used official digitized block maps (Integrated Administration and Control System database), supplemented with data on within-block boundaries of different crops based on field notes and aerial photographs. The maps were further supplemented with digitized rivers, major ditches, roads, forests and different open, bushy or wooded islets, as well as farmsteads and other built-up areas. These data were combined in a digitized vector map containing spatially explicit, georeferenced data on all crops cultivated in our study landscapes. During field surveys, we noted all spring-sown cereals on one hand and various types of sown grasslands on the other. Crop types included (i) non-permanent, sown leys for silage and (ii) pastures on arable land, often retained for some years as a part of crop rotation, (iii) spring-sown cereals, (iv) autumn-sown cereals, (v) spring-sown dicots (oilseed rapes, broad bean etc.), (vi) autumn-sown oilseed rape and caraway, (vii) fallows, and (viii) stubble fields (i.e. no-till springsown crops, including both cereals and oilseed rape), which together comprised all arable land within each sampling unit. Note that silage leys and pastures on arable land are different as habitats, the former being in intensive cultivation and the latter representing less intensive habitat for birds, existing for several years though not necessarily permanent in a strict sense. Using crop types rather than separating between all crops better reflects functional habitat types for farmland birds (Hiron et al. 2015).

We thereafter established circular sampling units with a radius of $200 \mathrm{~m}$ (12.56 ha) across all survey areas. The number of sampling units was maximized within the survey areas given three constraints; (i) at least $50 \%$ of the plot had to consist of open farmland, (ii) the sampling units were exclusive, i.e. no spatial overlap among the sampling units was allowed, and (iii) the centroid of a sampling unit had to be on an actively farmed field parcel. We discarded all sampling units containing abandoned farmland, which either consisted of grassy or bushy former fields. Thereafter we counted the number of territories of the 20 bird species breeding in open farmland in this study area (see below for details) for each sampling unit, 
along with information on land cover data. Following this procedure we obtained 657 sampling units, covering some 8200 ha of farmland across southern Finland. The selected sampling units included observations of 7624 individual bird territories of the selected 20 farmland bird species (Supporting material $\mathrm{S} 2$ ).

\section{Calculation of response variables}

In this study we selected all open-farmland bird species, belonging to two ecological groups: (i) 12 species breeding on arable land and along open field boundaries (hereafter termed field nesters), and (ii) 8 bird species breeding primarily amongst bushes and higher herb vegetation in non-crop habitats, such as field boundaries and other edge habitats (hereafter termed non-crop nesters; see Supporting material S2). Thus we explicitly focused on bird species breeding in open farmland and not on farmland species breeding in forest edges or farmsteads (Josefsson et al. 2017). We classified farmland birds into these two groups based on earlier published classifications developed for Finnish conditions (Tiainen and Pakkala 2001). We used total species richness, the species richness of field nesters and non-crop nesters, as well as the diversity of farmland birds [using the inverse Simpson's index (1/ D)], as community response variables. In addition, we analysed abundances of four most common individual species: the field breeders skylark (3936 territories) and the meadow pipit (686 territories), and the noncrop nesters common whitethroat (924 territories) and winchat (443 territories).

\section{Calculation of landscape variables}

We calculated the following predictors corresponding to the current greening measures: (i) the proportion of fallows within the sampling units as a proxy for ecological focus areas; (ii) crop type diversity (see below for details) within the sampling units, and (iii) the proportion of grasslands (all types of grasslands except for rotational silage leys, i.e. crop type (i) listed in the section Field surveys and data preparation above) within the sampling units as a proxy for permanent and longer-term grasslands. Fallows are comprised of environmental fallows (i.e., a nonproductive field set aside for at least 2 years under an agri-environment scheme, Toivonen et al. 2013), other long-term fallows (combined on 421.0 ha in total, present in $41 \%$ of all sampling units), and rotational fallows with stubble or bare-ground fallows (in $8 \%$ of all sampling units totalling 100.2 ha). The two fallow types were combined because of the relatively low sample size of rotational fallows.

We included two groups of adjusting landscape variables in this study (Table 1). First, in order to describe the landscape structure in terms of non-crop landscape characteristics, we measured the following predictors: (i) distance to the nearest forest from the centroid of each sampling unit (following Piha et al. (2007); (ii) the proportion of built-up habitats (following Devictor and Jiguet 2007), including all builtup areas and human settlements, but in addition also small islets with trees or bushes found primarily close to roads, settlement and barns; and (iii) an index for field edge density describing the relative amount of non-crop field boundaries in the sampling units. We chose to measure distance to forests instead of proportion forests within the buffers because the former will more accurately describe the landscape context for all sampling units, including those which had no forests within 200 metres from the centroid (40\% of all 657 sampling units). We combined islets with trees or bushes with built-up areas because accounting for islets by themselves would not have been statistically feasible, as they constituted a tiny fraction of total land cover. We calculated the relative amount of field edge density by dividing the number of blocks intersecting with the sampling units with the area of arable land within respective sampling units. Thus, low values indicated a low relative density of field boundaries and high values a high relative density of field boundaries.

We constructed our measure of crop diversity using major crop types listed above instead of all available crop classes listed in the block database or stipulated in the national regulation on greening. A classification into major crop types by their sowing timing and taxonomy has been shown to be ecologically more relevant for farmland birds as compared to a more detailed distinction between crops as it is implemented in greening (Hiron et al. 2015). We defined crop type diversity as the inverse Simpson's index following Palmu et al. (2014), calculated on the proportions of seven groups of crop types recorded spatially explicitly for each sampling unit. Defined in this way our measure of crop diversity was highly correlated with 
Table 1 Summary statistics for explanatory variables and response variables based on the 657 sampling units (circular units with a radius of $200 \mathrm{~m}$ )

*See Supporting Material S2 for full species list, including numbers of observed territories per species

\begin{tabular}{lcll}
\hline Variable & Mean $\pm \mathrm{SD}$ & Range & Frequency (n, \%) \\
\hline Explanatory variables & & & \\
Distance to forests (m) & $219.9 \pm 172.2$ & $0.00-1064.0$ & $655(99.7)$ \\
Proportion built-up areas & $0.06 \pm 0.07$ & $0.00-0.41$ & $576(87.7)$ \\
Edge density & $0.04 \pm 0.02$ & $0.01-0.17$ & $657(100.0)$ \\
Proportion fallows & $0.07 \pm 0.15$ & $0.00-0.80$ & $294(44.7)$ \\
Crop diversity & $1.92 \pm 0.73$ & $1.00-5.36$ & $657(100.0)$ \\
Proportion grasslands & $0.04 \pm 0.10$ & $0.00-0.67$ & $164(25.0)$ \\
Response variables* & & & \\
Species richness & $4.2 \pm 1.9$ & $1.0-13.0$ & $657(100.0)$ \\
Species diversity & $2.7 \pm 1.2$ & $1.0-7.2$ & $657(100.0)$ \\
Richness field nesters & $2.3 \pm 1.2$ & $0.0-7.0$ & $630(95.9)$ \\
Richness non-crop species & $1.8 \pm 1.3$ & $0.0-7.0$ & $562(85.5)$ \\
Skylark & $6.0 \pm 4.8$ & $0.0-28.0$ & $621(94.5)$ \\
Meadow pipit & $1.0 \pm 1.5$ & $0.0-18.0$ & $329(50.1)$ \\
Common whitethroat & $1.4 \pm 1.4$ & $0.0-7.0$ & $465(70.8)$ \\
Whinchat & $0.7 \pm 0.9$ & $0.0-7.0$ & $300(45.7)$ \\
\hline
\end{tabular}

crop type richness $\left(r_{S}=0.74, P<0.0001\right)$, and equated to crop type richness only if crops had equal proportions within each sampling unit.

Our grassland variable included a variety of grasslands, including truly permanent grasslands and sown but grazed grasslands on arable land but not short-rotational silage leys, which were not grazed and typically kept for one or 2 years. Rotational grazed grasslands are typically kept for several years, and they covered 173.3 ha in total (present in $16 \%$ of all sampling units). In Finland, only $1.4 \%$ of the field area has been classified as permanent grassland for the whole country (Bascou 2012). Permanent grassland consisted of three different land-use types as specified in the Integrated Administration and Control System database: semi-natural permanent grazed pastures; semi-natural permanent grazed pastures on wetlands, and semi-natural grasslands characterised by herb- and grass-dominated vegetation, but not currently grazed or mown. Together, these permanent grasslands were found in $15 \%$ of the 659 sampling units, covering a total area of 110.6 ha.

\section{Statistical methods}

We found a significant moderate correlation between edge density and crop type diversity $\left(r_{P}=0.40\right)$. To account for collinearity between these predictors we regressed crop type diversity against edge density and used the residuals of this regression (Graham 2003) to measure crop type diversity, while accounting for field size. Thus, all predictor variables showed sufficiently low correlations with each other $\left(r_{P} \leq 0.30\right.$; Graham 2003; Zuur et al. 2009). We log-transformed all predictors to improve linearity and thereafter scaled the predictors to zero mean and unit variance. Scaling the predictors allowed us to assess the individual and joint effects of predictors given the average of other included predictors. We thereafter constructed individual statistical models for total species richness, species diversity (inverse Simpson's index) and abundance of the most common species by first including the three adjusting landscape variables (distance to forests, proportion of built-up areas within the circular sampling units, and farmland edge density) and the three variables corresponding to greening measures (crop diversity and the proportions of fallows and grasslands within the sampling units). We first defined full models considering all two-way interactions between the three adjusting landscape variables and the three variables corresponding to greening measures, and thereafter we removed all nonsignificant interactions one by one to simplify the models. All models included the survey area identity nested within a variable describing regional identity (Supporting Material S1), to control for non-independence between sampling units within the same survey 
area, and for larger-scale autocorrelation between regionally clustered survey areas (Zuur et al. 2009).

Total species richness of farmland birds was analysed using generalised linear mixed models with Poisson error distributions as implemented in the function glmer() available in the library lme4 (Bates et al. 2015), whereas species diversity was analysed using linear mixed models using the function lme() in the library nlme (Pinheiro et al. 2015). Finally, while analysing the abundances of the most common farmland birds we evaluated four alternative error structures (Poisson, zero-inflated Poisson, negative binomial and zero-inflated negative binomial) by comparing model AIC:s using the library glmmADMB (Fournier et al. 2012). Following this procedure, the abundance of skylarks, meadow pipits, and whinchats was modelled using a negative binomial distribution, whereas the common whitethroat was modelled using zero-inflated Poisson error distributions. We verified model assumptions by visual examinations of model residuals, and by confirming that model residuals were not spatially autocorrelated using correlograms as implemented in the library ncf (Bjornstad 2016).

\section{Results}

\section{Community-level effects}

The proportion of grasslands had a consistently positive effect on all measures of species richness and diversity (Table 2, Fig. 2a-b). However, the positive effect of increasing proportions of grasslands for total species richness, total species diversity and species richness of open breeders increased with decreasing proportions of built-up areas. Given the mean proportion of built-up areas in our sample units (0.06), an increasing proportion of grasslands increased the total species richness, total species diversity and species richness of open breeders (Supporting Material S3-4). Subdividing the data based on the median into high and low proportions in built-up areas (mean $=0.11$ in high and 0.02 in low) showed that overall species richness and richness of open breeders significantly increased with increasing proportions of grasslands given low proportions in built-up areas (slope $\geq 1.09, P \leq 0.008$; Supporting Material S3), but not given high proportions (slope $\geq 0.39, P \leq 0.092$; Supporting Material S3). Species diversity significantly increased under both low and high proportions of built-up areas based on the above subdivision (Supporting Material S3). Here, the relationship only became non-significant as proportions in built-up areas exceeded 15-20\% (Supporting Material S4). An increasing proportion of fallows significantly increased bird species diversity (Fig. 2c) and richness of edge species, but not total species richness or richness of in-field breeders. Increasing crop diversity had no effect on any diversity component (Table 2).

Total species richness and diversity, and richness of field nesters and non-crop nesters all consistently increased with increasing field edge density, which had the strongest effect out of the main term predictors (Table 2, Fig. 2d). In contrast, increasing proportions of built-up areas had different effects on the four diversity components. Species diversity and richness of non-crop nesters significantly increased with increasing proportions of built areas, whereas richness of open nesters significantly declined and total species richness was unaffected (Table 2). Finally, increasing distance to forests consistently increased all diversity components. The proportion of built-up areas did not affect overall species richness, whereas field nesters significantly decreased and non-crop nesters significantly increased with increasing proportions of builtup areas (Table 2).

\section{Species-specific effects}

The three greening variables had contrasting effects on the abundances of the four most abundant bird species (Table 3). First, an increasing proportion of grasslands significantly increased the abundances of meadow pipits and common whitethroats, independently of adjusting landscape characteristics, whereas whinchat abundance increased with increasing proportions of grasslands in combination with high distances to forests (Supporting Material S3). Skylark abundance was not affected by an increasing proportion of grasslands (Table 3).

The effects of increasing proportions of fallows were significant only in interactions with landscape variables. On the one hand, increasing proportions of fallows far away from forests significantly increased skylark abundance while close to forests they did not (Supporting Material S3-4). This interactive effect was not significant for the other three species (Table 3). On the other hand, increasing field edge 
Table 2 Responses in species richness, species diversity, richness of in-field nesters and richness of non-crop nesters to landscape context (distance to forests, proportion built-up areas and field edge density) and potential greening measures (proportion fallows, crop diversity and proportion), and significant interactions between landscape and greening variables

\begin{tabular}{|c|c|c|c|c|c|c|}
\hline & $\begin{array}{l}\text { Estimate } \pm \mathrm{SE} \\
\text { Species richness (total) }\end{array}$ & $\mathrm{z}$ & $P$ & $\begin{array}{l}\text { Estimate } \pm \mathrm{SE} \\
\text { Species diversity (Inverse } \\
\text { Simpson's index) }\end{array}$ & $\mathrm{t} / \mathrm{z}^{*}$ & $P$ \\
\hline (Intercept) & $1.413 \pm 0.045$ & & & $2.725 \pm 0.109$ & & \\
\hline Distance to forests & $0.166 \pm 0.024$ & 6.81 & $<0.0001$ & $0.111 \pm 0.054$ & 2.05 & 0.0406 \\
\hline Proportion built-up areas & $-0.213 \pm 0.343$ & -0.62 & 0.5359 & $2.013 \pm 0.811$ & 2.48 & 0.0133 \\
\hline Edge density & $4.864 \pm 1.355$ & 3.59 & 0.0003 & $10.353 \pm 3.278$ & 3.16 & 0.0017 \\
\hline Proportion fallows & $0.324 \pm 0.168$ & 1.93 & 0.0538 & $0.878 \pm 0.419$ & 2.10 & 0.0365 \\
\hline Crop diversity & $0.124 \pm 0.102$ & 1.22 & 0.2230 & $-0.114 \pm 0.249$ & -0.46 & 0.6454 \\
\hline Proportion grasslands & $0.938 \pm 0.232$ & 4.04 & $<0.0001$ & $3.244 \pm 0.607$ & 5.34 & $<0.0001$ \\
\hline \multirow{2}{*}{$\begin{array}{l}\text { Prop. built- } \\
\text { up } \times \text { grasslands }\end{array}$} & $-9.779 \pm 3.442$ & -2.84 & 0.0045 & $-22.974 \pm 8.035$ & -2.86 & 0.0044 \\
\hline & $\begin{array}{l}\text { Species richness, } \\
\text { in-field nesters }\end{array}$ & & & $\begin{array}{l}\text { Species richness, } \\
\text { non-crop nesters }\end{array}$ & & \\
\hline (Intercept) & $0.830 \pm 0.026$ & & & $0.569 \pm 0.073$ & & \\
\hline Distance to forests & $0.203 \pm 0.032$ & 6.31 & $<0.0001$ & $0.130 \pm 0.037$ & 3.53 & 0.0004 \\
\hline Proportion built-up areas & $-1.906 \pm 0.479$ & -3.98 & $<0.0001$ & $1.372 \pm 0.037$ & 3.53 & 0.0004 \\
\hline Edge density & $3.936 \pm 1.733$ & 2.27 & 0.0231 & $7.123 \pm 2.015$ & 3.53 & 0.0004 \\
\hline Proportion fallows & $0.132 \pm 0.223$ & 0.59 & 0.5538 & $0.622 \pm 0.250$ & 2.49 & 0.0127 \\
\hline Crop diversity & $0.131 \pm 0.136$ & 0.96 & 0.3351 & $0.102 \pm 0.153$ & 0.67 & 0.5050 \\
\hline Proportion grasslands & $0.833 \pm 0.297$ & 2.81 & 0.0050 & $0.768 \pm 0.345$ & 2.23 & 0.0258 \\
\hline $\begin{array}{l}\text { Prop. built- } \\
\text { up } \times \text { grasslands }\end{array}$ & $-10.464 \pm 4.905$ & -2.13 & 0.0329 & & & \\
\hline
\end{tabular}

All significant responses shown in bold

*Significance tests on species diversity based on t-statistics

density moderated the positive effects of fallows on the abundances of skylarks, meadow pipits and whinchats. An increasing proportion of fallows significantly increased skylark and meadow pipit abundances when edge density was low, but not when edge density was high (Supporting Material S3-4). Whinchat abundances significantly increased with increasing proportions of fallows overall but more strongly when edge density was low than when it was high (Supporting Material S3-4).

Increasing crop diversity had a highly significant positive effect on skylark abundances, whereas effects of crop diversity were modulated by adjusting landscape variables for the abundances of meadow pipits and common whitethroats. Meadow pipit abundance increased with increasing crop diversity close to forests, but the slope decreased with increasing distance to forests. The significant interaction between crop diversity and edge density on common whitethroat abundances was caused by opposing trends in crop diversity when edge density was extremely low (negative trend) or extremely high (positive trend) (Supporting Material S4). The whinchat abundance was not related to crop type diversity.

\section{Discussion}

Our analysis of farmland field types corresponding to options available under current CAP greening measures demonstrates that the availability of grasslands in cereal-dominated boreal farmland would have a potential to benefit farmland bird diversity. Increasing proportions of fallow land would also benefit farmland birds but to a lesser extent, whereas crop diversity, within its current range supported also by greening, 
Fig. 2 Marginal mean effects $( \pm 95 \%$ confidence intervals), given the average effects of the other predictors (see Table 2), of proportions of grassland on bird species richness (a), proportions of grassland on bird diversity (b),

proportions of fallows on bird diversity (c) and field edge density on bird species richness (d). Note that grassland effects on bird species richness (a) and diversity (b) were stronger given low values of built-up areas (Table 2, Supporting material S3-4)
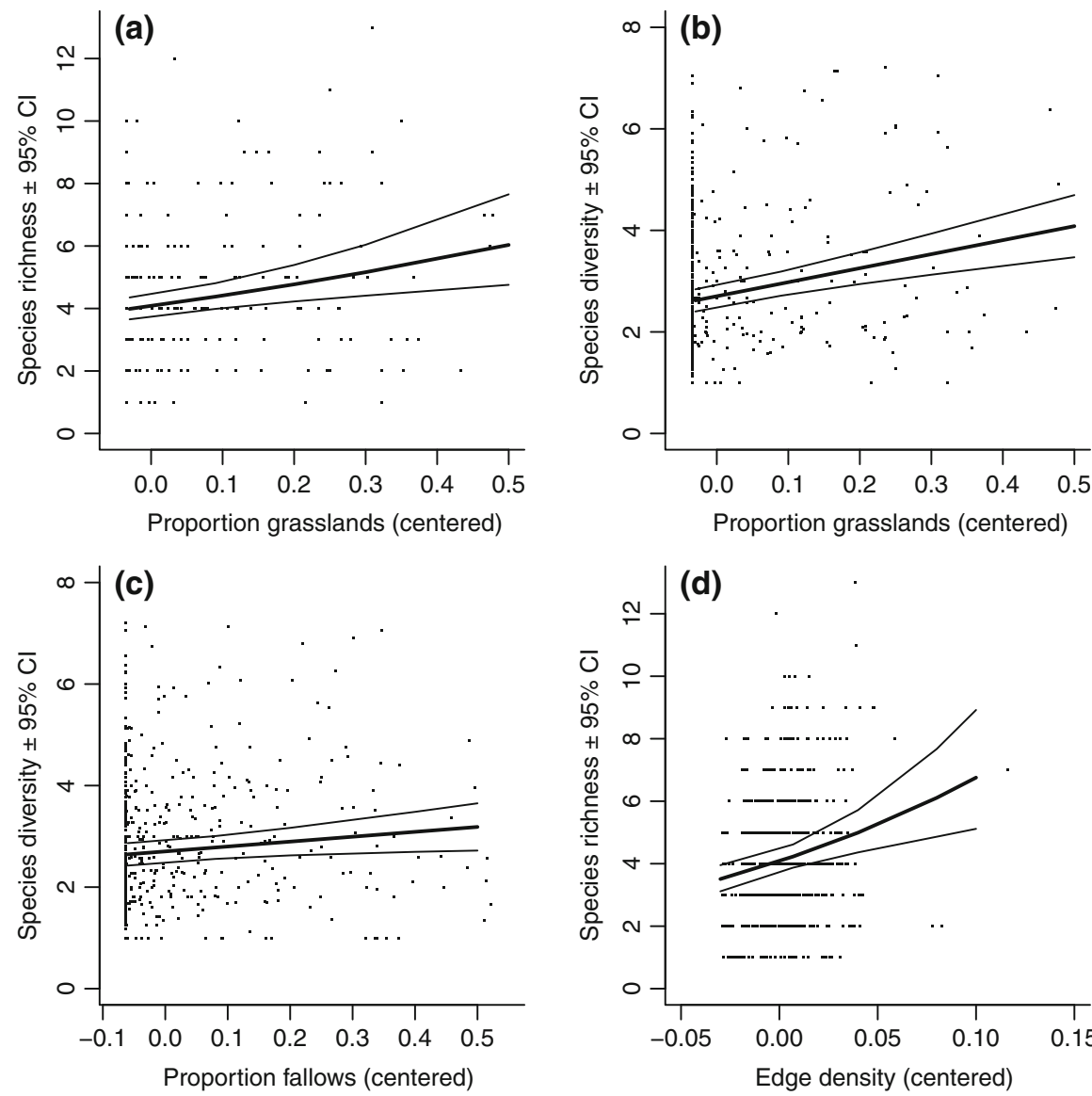

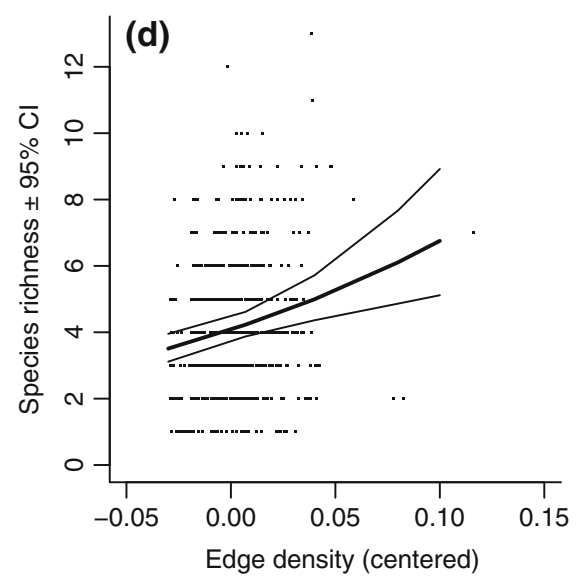

Table 3 Species-specific responses in the two most common in-field nesting bird species (skylark and meadow pipit) and non-crop nesting species (common whitethroat and whinchat)

\begin{tabular}{|c|c|c|c|c|}
\hline & Skylark & Meadow pipit & $\begin{array}{l}\text { Common } \\
\text { whitethroat }\end{array}$ & Whinchat \\
\hline (Intercept) & $1.67 \pm 0.12$ & $-0.27 \pm 0.16$ & $0.31 \pm 0.07$ & $-0.55 \pm 0.10$ \\
\hline Distance to forests & $0.47 \pm 0.03 * * *$ & $0.46 \pm 0.07 * * *$ & $0.07 \pm 0.04$ & $0.25 \pm 0.07 * * *$ \\
\hline Proportion built-up areas & $-4.64 \pm 0.44 * * *$ & $-3.59 \pm 0.97 * * *$ & $3.00 \pm 0.53 * * *$ & $-2.48 \pm 0.95 * *$ \\
\hline Edge density & $2.25 \pm 1.72$ & $7.42 \pm 3.81^{(*)}$ & $10.58 \pm 2.39 * * *$ & $10.97 \pm 3.75 * *$ \\
\hline Proportion fallows & $0.14 \pm 0.20$ & $1.95 \pm 0.38 * * *$ & $0.51 \pm 0.30^{(*)}$ & $1.96 \pm 0.35^{* * *}$ \\
\hline Crop diversity & $0.54 \pm 0.12 * * *$ & $1.08 \pm 0.28 * * *$ & $-0.36 \pm 0.20^{(*)}$ & $0.14 \pm 0.27$ \\
\hline Proportion grasslands & $-0.39 \pm 0.29$ & $1.25 \pm 0.60^{*}$ & $0.89 \pm 0.36^{*}$ & $1.90 \pm 0.56 * * *$ \\
\hline Dist. forests $\times$ prop. fallows & $0.71 \pm 0.25^{* *}$ & & & \\
\hline Dist. forests $\times$ crop diversity & & $-0.69 \pm 0.35^{*}$ & & \\
\hline Dist. forests $\times$ prop. fallows & & & & $1.94 \pm 0.68 * *$ \\
\hline Edge density $\times$ prop. fallows & $-24.77 \pm 11.85^{*}$ & $-68.01 \pm 23.00^{* *}$ & & $-58.57 \pm 19.19 * *$ \\
\hline $\begin{array}{l}\text { Edge density } \times \text { crop } \\
\text { diversity }\end{array}$ & & & $15.09 \pm 5.94 *$ & \\
\hline
\end{tabular}

All significant responses shown in bold 
would not considerably enhance farmland bird species richness or diversity. Notably, our study demonstrates that a high density of field boundaries in open farmland consistently benefit farmland birds. Concerning species richness and diversity, the relative effect size of edge density was much stronger compared to effects of high crop diversity and proportions of grasslands and fallows, whereas concerning individual species, effects of greening measures were to a higher extent influenced by landscape context. In the following, we discuss the implications of our results for the conservation of farmland bird diversity by EU greening measures in mosaic farmland landscapes.

Effects of grasslands and fallows

Amongst the three greening measures, increasing proportions of grasslands had the strongest positive effect on farmland bird assemblages. Given average values in all other predictors, an increase in grasslands from 0 to $67 \%$ increased total species richness from 4 to 6 at the scale of the 12.56 ha sampling units, and this increase was even stronger given the absence of built-up areas (Supporting Material S4). In our cerealdominated agricultural landscapes, grasslands (and fallows) may represent important but relatively rare habitat types that already at low acreages benefit birds that prefer non-cereal grassy habitats (Wretenberg et al. 2010). While we acknowledge that our definition of grasslands included a wide variety of grassland types, with largely unknown management regimes, our results suggest they had sufficiently similar ecological characteristics on the subset of farmland birds included in our study (c.f. Ernst et al. 2018). Because birds are highly mobile and relatively flexible in terms of habitat use, they can utilise different grassland types to a larger extent than some insect groups that are dependent on vegetation diversity or grassland continuity (Smith et al. 2014). Many bird species can be expected to benefit from true permanent grasslands with heterogeneous vegetation structure in comparison with young grasslands and in particular with homogenous swards of rotational grasslands (Wilson et al. 2005; Herzon et al. 2014), given that permanent grasslands are not too intensively managed (Zingg et al. 2018).

In addition, fallows benefited non-crop nester species richness and total diversity of farmland birds, as well as the abundance of skylarks and meadow pipits, but regarding the two latter in slightly different contexts. Whereas the meadow pipit benefited from fallows when edge density was low, the skylark was strongly limited by proximity to forests and only fallows far away from forests benefited the species (with an increase of roughly $50 \%$ in local abundance given the range of fallows ( $0 \%$ to $80 \%)$ within the 12.56 ha sampling units; see Table 1 and Supporting Material S4). Both results reflect known habitat selection patterns of the species (Piha et al. 2003; Vepsäläinen et al. 2010). In particular fallows sown with a meadow plant mixture are extensively used by foraging farmland birds, and the relative value of fallows for farmland birds may be further modified by promoting short-term fallows sown with meadow seed-mixture in landscapes dominated by leys (Toivonen et al. 2013). Our results demonstrate that promoting fallows and grasslands in open farmland are likely to benefit farmland birds to a much higher extent than by increasing crop diversity in cereal-dominated farmland (Josefsson et al. 2017).

\section{Effects of crop diversity}

Our result show that increasing crop diversity does not benefit overall farmland bird assemblages given the current diversity of crops and landscape structure in Southern Finland, but may benefit a subset of farmland bird species. While increasing crop diversity has been found to be beneficial for some arthropod groups in structurally simple landscapes (Palmu et al. 2014), a similar definition of crop diversity seems to benefit only a subset of birds breeding in open farmland (Josefsson et al. 2017; this study). Similar benefits of crop diversity based on individual crops have not been found (Hiron et al. 2015; Josefsson et al. 2017). Therefore, actual implementations of the greening measure crop diversity most likely benefits birds to even a smaller extent than indicated in our study.

The only species that directly benefited from increasing crop diversity was the skylark, which strongly depends on open farmland and is known to shift nesting sites according to the growth stage of crops (Hoffman et al. 2016). High crop diversity may provide complementary or supplementary resources such as feeding and nesting sites (Fahrig et al. 2011), and conditions may change in a crop-specific way over the season. In addition, our results suggest that common whitethroats benefit from high crop diversity 
in landscapes with a very high field edge density (Supporting Material S4). Whereas field edges are the main farmland habitat for common whitethroats, high crop diversity may increase insect prey densities and therefore benefit the species via habitat complementation effects (Vasseur et al. 2013).

\section{Effects of adjusting landscape variables}

Whilst our primary motivation for including distance to forests and proportions of built-up areas was to test for interactive effects with management options corresponding to greening measures, the independent and consistently beneficial effect of increasing field edge density for farmland bird species richness and diversity is of major importance. Amongst the three adjusting landscape variables, field edge density had the strongest effect on farmland bird assemblages, and beneficial effects of field edge density were equally strong on species richness of in-field breeders and edge species. Our results strongly suggest that retaining non-crop field boundaries across the farmland is amongst the most important single factors that could be targeted in management strategies for promoting farmland birds.

Regarding individual species, increasing field edge densities significantly increased the abundances of whinchats and common whitethroats, given average values in all other predictors. In contrast, the in-field species skylark and meadow pipit did not show similar responses, which to some extent may be explained by the structural heterogeneity of the field boundaries. Open ditch drainage provides within-field edges which Marja et al. (2013) showed to benefit meadow pipits and skylarks in comparison to subsurface drainage. While we did not explicitly measure the structural properties of the field boundaries, their habitat composition varied widely in our study region. In our study, most field boundaries were placed along ditches or field roads with predominantly open vegetation, but many had scattered bushes or trees that may have deterred in-field species.

The potential of CAP greening measures to benefit farmland birds

Whereas our results give some support to the measures chosen for the greening policy, the level of ambitions of the greening falls short for improving the status quo in this country (see also Pe'er et al. 2017). In our study region, various fallows and set-asides covered $15 \%$ of the utilised agricultural area, of which $9 \%$ are maintained under an agri-environment scheme of environmental fallow in the present programming period (Natural Resources Institute Finland 2017). There were $7 \%$ of fallow in our data, which also exceeds the minimum 5\% under the greening obligation. In addition, support for legumes and rotational coppice as an option for ecological focus areas may decrease the fallow areas. A recent review suggests that the predominance of nitrogen-fixing crops grown as ecological focus areas and their conventional management are unlikely to provide significant benefits for biodiversity (European Commission 2017). Though the area under faba bean (Vicia faba) increased by $200 \%$ from 2013 to 2017 in Finland (Natural Resources Institute Finland 2017), the benefits for biodiversity are unknown.

The current occurrence of permanent grassland in mainland Finland stands at only $1.4 \%$ of the utilized agricultural area, making their retention under greening of marginal relevance to biodiversity nationally. In Sweden, the measure of permanent grasslands is coordinated at a national level and requires little or no action by farmers (Söderberg 2016). However, as our results show, a wide variety of grasslands has the potential to significantly enhance farmland bird diversity, and hence supporting other types of grasslands in arable-dominated agricultural landscapes should be promoted. Interventions for increasing grassland acreages could be included as voluntary measures under agri-environment schemes, such as the ley support targeting soil and biodiversity conservation in cereal-dominated regions in Southern Sweden (Jordbruksverket 2018).

Our results indicate that the crop diversification measure may be beneficial for some farmland birds, but only if it adds a structurally contrasting field type to a farm's area (also see Hiron et al. 2015; Josefsson et al. 2017). Since in Southern Finland, the two dominating rotating crops are spring-sown (barley and oilseed rape), it is the third crop option on farms with at least 30 ha fields that would define the ecological additionality of the measure. Our results indicate that this additionality is likely to be particularly high if greening introduces grasslands to the farm.

Finally, more evidence is needed to justify an exemption of the regions with a high cover of forest, 
which is most of the country, from the greening measures. For example, while fallows benefit farmland birds in relatively open boreal farmland (Herzon et al. 2011), they benefit other taxa, such as butterflies, in forest-dominated mosaic landscapes (Toivonen et al. 2016). Recent work in Sweden suggests that low requirements on implementation limit environmental benefits of ecological focus areas (Dänhardt et al. 2017). It also remains unclear to what extent the ecological focus area obligation promoted establishment of new fallows, compared to the various types of fallows and set-asides that already existed in Southern Finland (Herzon et al. 2011). Research into the types of fallows, their longevity, placement within the landscape, and management, is needed to understand better the realised value of this measure. It is also possible that greening measures benefit biodiversity by directly or indirectly protecting marginal agricultural landscapes with high biodiversity from being abandoned (c.f. Kampmann et al. 2012).

\section{Conclusions}

Our results provide much needed evidence on plausible benefits of the greening measures for farmland birds in mosaic landscapes. We demonstrate that the greening policy, as it is currently implemented under the CAP, will likely generate highly context-dependent effects on individual species breeding in open farmland, but will not benefit the richness or diversity of farmland bird assemblages. First, we found no evidence that increasing crop diversity to three crops will benefit species richness or diversity of farmland birds, except some of the most abundant farmland bird species, most notably the skylark. Secondly, though retaining fallows as ecological focus areas has a high potential to increase farmland bird diversity, the greening obligations are currently too low, and farmers prefer less biodiversity-friendly options than fallows for implementing ecological focus areas (Pe'er et al. 2016). Finally, the value of permanent grassland obligation is likely to remain negligible because of its marginal extent, although permanent grasslands as such are important for biodiversity.

We show that maintaining semi-natural grasslands and grazed arable pastures strongly benefits farmland birds. Our results also indicate that specific placement of the measures across the landscape can further enhance potential benefits: most measures should be implemented in open farmland, with only small proportions of land close to built-up areas or forest. Based on our results, a policy requirement that would most consistently benefit farmland birds is to retain the network of non-crop field boundaries across open farmland. This, however, is not addressed in the national agri-environment schemes, while enlargement of field parcels and replacement of open ditches with subsurface drains is an active agricultural policy target aiming at further modernisation of Finnish agriculture (Hiironen 2012).

Acknowledgements We thank Hannu Holmström, Sampo Laukkanen, Kalle Meller, Timo Pakkala, Jarmo Piiroinen and the late Hannu Tammelin for assistance in bird monitoring. We acknowledge the Finnish Ministry of Agriculture and Forestry, the Ministry of Environment, Alands Landskapsstyrelse and Finnish Game and Fisheries Research Institute for funding the data collection. JE was supported by the strategic research area BECC and by the ERA-NET project MULTAGRI. During the preparation phase of the paper, JT and TS were supported by the OPAL-Life project. IH was supported by the HNV-Link project under the Horizon2020 programme (Project Reference 696391).

Open Access This article is distributed under the terms of the Creative Commons Attribution 4.0 International License (http:// creativecommons.org/licenses/by/4.0/), which permits unrestricted use, distribution, and reproduction in any medium, provided you give appropriate credit to the original author(s) and the source, provide a link to the Creative Commons license, and indicate if changes were made.

Funding Funding was supported by Svenska Forskningsrådet Formas and H2020 European Research Council.

\section{References}

Bascou P (2012) The concept and purpose of greening and specifically EFA. Presentation at delivering environmental benefits through ecological focus areas. A land use policy group workshop, 6 March 2012, Scotland House, Brussels

Batáry P, Baldi A, Kleijn D, Tscharntke T (2011) Landscapemoderated biodiversity effects of agri-environmental management: a meta-analysis. Proc $R$ Soc B 278:1894-1902

Bates D, Maechler M, Bolker B, Walker S (2015)_lme4: linear mixed-effects models using Eigen and $\mathrm{S} 4 \_$. R package version 1.1-9

Bjornstad ON (2016) Ncf: spatial nonparametric covariance functions. R Package Version 1, pp 1-7. https://CRAN.Rproject.org/package $=$ ncf 
Brotons L, Wolff A, Paulus G, Martin JL (2005) Effect of adjacent agricultural habitat on the distribution of passerines in natural grasslands. Biol Conserv 124:407-411

Dänhardt J, Nilsson L, Hristov J, Alkan Olsson J, Brady M, Olsson P, Smith HG, Clough Y (2017) Ekologiska fokusarealer i samverkan. Utvärdering av effekter på ekosystemtjänster, jordbruk och administration. Naturvårdsverket. (In Swedish)

Devictor V, Jiguet F (2007) Community richness and stability in agricultural landscapes: the importance of surrounding habitats. Agric Ecosyst Environ 120:179-184

Dicks LV, Hodge I, Randall NP, Scharlemann JP, Siriwardena GM, Smith HG, Smith RK, Sutherland WJ (2014) A transparent process for "evidence-informed" policy making. Conserv Lett 7:119-125

Ernst LM, Tscharntke T, Batáry P (2018) Grassland management in agricultural vs. forested landscapes drives butterfly and bird diversity. Biol Conserv 216:51-69

European Commission (2011) Our life insurance, our natural capital: an EU biodiversity strategy to 2020. European Commission Brussels, Belgium

European Commission (2013) CAP reform-an explanation of the main elements. European Commission Brussels, Belgium

European Commission (2017) Evaluation study of the payment for agricultural practices beneficial for the climate and the environment. Executive summary. European Commission Brussels, Belgium

Fahrig L, Baudry J, Brotons L, Burel FG, Crist TO, Fuller RJ, Sirami C, Siriwardena G, Martin JL (2011) Functional landscape heterogeneity and animal biodiversity in agricultural landscapes. Ecol Lett 14:101-112

Finlex (2017) Statsrådets förordning om ändring av statsrådets förordning om grundstöd, förgröningsstöd och stöd till unga jordbrukare. (In Swedish and Finnish). http://www. finlex.fi/sv/laki/alkup/2017/20170337

Fournier DA, Skaug HJ, Ancheta J, Ianelli J, Magnusson A, Maunder M, Sibert J (2012) AD Model Builder: using automatic differentiation for statistical inference of highly parameterized complex nonlinear models. Optim Methods Softw 27:233-249

Graham MH (2003) Confronting multicollinearity in ecological multiple regression. Ecology 84:2809-2815

Herzon I, Ekroos J, Tiainen J, Seimola T, Vepsäläinen V (2011) Importance of set-aside for breeding birds of open farmland in Finland. Agric Ecosyst Environ 143:3-7

Herzon I, Marja R, Kondratyev A, Menshikova S (2014) Seasonal and spatial patterns of farmland bird communities across an agricultural landscape in the Northwest Russia. Agric Ecosyst Environ 183:78-85

Hiironen J (2012) On the impacts and profitability of farmland consolidation. Dissertation, Aalto University (in Finnish with English summary)

Hiron M, Berg $\AA$, Eggers S, Berggren $\AA$, Josefsson J, Pärt T (2015) The relationship of bird diversity to crop and noncrop heterogeneity in agricultural landscapes. Landscape Ecol 30:2001-2013

Hoffman J, Wittchen U, Stachow U, Berger G (2016) Moving window abundance - A method to characterise the abundance dynamics of farmland birds: The example of Skylark (Alauda arvensis). Ecol Indic 60:317-328.
Jordbruksverket (2018) Miljöersättning för vallodling. http:// www.jordbruksverket.se/jordbruksverketslattlastasidor/ stodtilllandsbygden/jordbrukarstod/miljoersattningar/miljoe rsattningforvallodling.4.54a6715614b7cb03c2e3a862.html. Accessed 22 Mar 2018

Josefsson J, Berg Å, Hiron M, Pärt T, Eggers S (2017) Sensitivity of the farmland bird community to crop diversification in Sweden: does the CAP fit? J Appl Ecol 54:518-526

Kampmann D, Lüscher A, Konold W, Herzog F (2012) Agrienvironment scheme protects diversity of mountain grassland species. Land Use Policy 29:569-576

Kleijn D, Rundlöf M, Scheper J, Smith HG, Tscharntke T (2011) Does conservation on farmland contribute to halting the biodiversity decline? Trends Ecol Evol 26:474-481

Marja R, Herzon I, Rintala J, Tiainen J, Seimola T (2013) Type of agricultural drainage modifies the value of fields for farmland birds. Agric Ecosyst Environ 165:184-189

Natural Resources Institute Finland 2017. Utilised agricultural area 2016-preliminary on 30 June, 2016. http://stat.luke. fi/en/utilised-agricultural-area-2016-regional-preliminarydata_en. Accessed Apr 2017

Palmu E, Ekroos J, Hanson HI, Smith HG, Hedlund K (2014) Landscape-scale crop diversity interacts with local management to determine ground beetle diversity. Basic Appl Ecol 15:241-249

Pe'er G, Dicks LV, Visconti P, Arlettaz R, Báldi A, Benton TG, Collins S, Dieterich M, Gregory RD, Hartig F, Henle K, Hobson PR, Kleijn D, Neumann RK, Robijns T, Schmidt J, Shwartz A, Sutherland WJ, Turbé A, Wulf F, Scott AV (2014) EU agricultural reform fails on biodiversity. Science 344:1090-1092

Pe'er G, Lakner S, Müller R, Passoni G, Bontzorlos V, Clough D, Moreira F, Azam C, Berger J, Bezak P, Bonn A, Hansjürgens B, Hartmann L, Kleemann J, Lomba A, Sahrbacher A, Schindler S, Schleyer C, Schmidt J, Schüler S, Sirami C, von Meyer-Höfer M, Zinngrebe Y (2017) Is the CAP fit for purpose? An evidence-based fitness check assessment. German Centre for Integrative Biodiversity Research (iDiv), Halle-Jena-Leipzig, Leipzig

Pe'er G, Zinngrebe Y, Hauck J, Schindler S, Dittrich A, Zingg A, Tscharntke T, Oppermann R, Sutcliffe LME, Sirami C, Schmidt J, Hoyer C, Schleyer C, Lakner S (2016) Adding some green to the greening: improving the EU's ecological focus areas for biodiversity and farmers. Conserv Lett 10:517-530

Perkins AJ, Maggs HE, Watson A, Wilson JD (2011) Adaptive management and targeting of agri-environment schemes does benefit biodiversity: a case study of the corn bunting Emberiza calandra. J Appl Ecol 48:514-522

Pickett SRA, Siriwardena GM (2011) The relationship between multi-scale habitat heterogeneity and farmland bird abundance. Ecography 34:955-969

Piha M, Pakkala T, Tiainen J (2003) Habitat preferences of the Skylark Alauda arvensis at territory and landscape scales in agricultural landscapes of southern Finland. Ornis Fennica 80:97-110

Piha M, Tiainen J, Holopainen J, Vepsäläinen V (2007) Effects of land-use and landscape characteristics on avian diversity and abundance in a boreal agricultural landscape with organic and conventional farms. Biol Conserv 140:50-61 
Pinheiro J, Bates D, DebRoy S, Sarkar D, R Core Team (2015) _nlme: linear and nonlinear mixed effects models_. R package version 3.1-121

Scheper J, Holzschuh A, Kuussaari M, Potts SG, Rundlöf M, Smith HG, Kleijn D (2013) Environmental factors driving the effectiveness of European agri-environmental measures in mitigating pollinator loss-a meta-analysis. Ecol Lett 16:912-920

Smith HG, Birkhofer K, Clough Y, Ekroos J, Olsson O, Rundlöf M (2014) Beyond dispersal: the role of animal movement in modern agricultural landscapes. In: Hansson LA, Åkesson S (eds) Animal movement across scales. Oxford University Press, Oxford, pp 51-70

Söderberg T (2016) Förgröningen i praktiken. Jordbruksverket Rapp 8:1-60 (In Swedish)

Tiainen J, Pakkala T (2001) Birds. In: Pitkänen M, Tiainen J (Eds.), Biodiversity of agricultural landscapes in Finland. BirdLife Finland Conservation Series, vol 3, pp 33-50

Tiainen J, Seimola T (2014) Density variation among habitats of south Finnish farmland. Linnut-vuosikirja 2013:70-77 (in Finnish with English summary)

Toivonen M, Herzon I, Helenius J (2013) Environmental fallows: novel vegetation type in a boreal landscape. Biol Conserv 159:355-366

Toivonen M, Herzon I, Kuussaari M (2016) Community composition of butterflies and bumblebees in fallows: niche breadth and dispersal capacity modify responses to fallow type and landscape. J Insect Conserv 20:23-34 van Buskirk J, Willi Y (2004) Enhancement of farmland biodiversity within set-aside land. Conserv Biol 18:987-994

Vasseur C, Joannon A, Aviron S, Burel F, Meynard JM, Baudry J (2013) The cropping systems mosaic: how does the hidden heterogeneity of agricultural landscapes drive arthropod populations? Agric Ecosyst Environ 166:3-14

Vepsäläinen V, Tiainen J, Holopainen J, Piha M, Seimola T (2010) Improvements in the Finnish agri-environment scheme are needed to support rich farmland avifauna. Ann Zool Fennici 47:287-305

Wilson JD, Whittingham MJ, Bradbury RB (2005) The management of crop structure: a general approach to reversing the impacts of agricultural intensification on birds? Ibis 147:453-463

Wretenberg J, Pärt T, Berg § (2010) Changes in local species richness of farmland birds in relation to land-use changes and landscape structure. Biol Conserv 143:375-381

Zingg S, Grenz J, Humbert J-Y (2018) Landscape-scale effects of land use intensity on birds and butterflies. Agric Ecosyst Environ 267:119-128

Zuur AF, Ieno EN, Walker NJ, Saveliev AA, Smith G (2009) Mixed effects models and extensions in ecology with R. Springer, New York

Publisher's Note Springer Nature remains neutral with regard to jurisdictional claims in published maps and institutional affiliations. 